\title{
Glacier changes in the Karakoram region mapped by multimission satellite imagery
}

\author{
M. Rankl ${ }^{1}$, C. Kienholz ${ }^{2}$, and M. Braun ${ }^{1}$ \\ ${ }^{1}$ Institute of Geography, University of Erlangen-Nuremberg, Wetterkreuz 15, 91058 Erlangen, Germany \\ ${ }^{2}$ Geophysical Institute, University of Alaska Fairbanks, 903 Koyukuk Drive, Fairbanks, AK 99775-7320, USA \\ Correspondence to: M. Rankl (melanie.rankl@fau.de)
}

Received: 30 June 2013 - Published in The Cryosphere Discuss.: 13 August 2013

Revised: 27 March 2014 - Accepted: 11 April 2014 - Published: 23 May 2014

\begin{abstract}
Positive glacier-mass balances in the Karakoram region during the last decade have fostered stable and advancing glacier termini positions, while glaciers in the adjacent mountain ranges have been affected by glacier recession and thinning. In addition to fluctuations induced solely by climate, the Karakoram is known for a large number of surge-type glaciers. The present study provides an updated and extended inventory on advancing, stable, retreating, and surge-type glaciers using Landsat imagery from 1976 to 2012. Out of 1219 glaciers the vast majority showed a stable terminus (969) during the observation period. Sixty-five glaciers advanced, 93 glaciers retreated, and 101 surge-type glaciers were identified, of which 10 are new observations. The dimensional and topographic characteristics of each glacier class were calculated and analyzed. Ninety percent of nonsurge-type glaciers are shorter than $10 \mathrm{~km}$, whereas surge-type glaciers are, in general, longer. We report short response times of glaciers in the Karakoram and suggest a shift from negative to balanced/positive mass budgets in the 1980s or 1990s. Additionally, we present glacier surface velocities derived from different SAR (synthetic aperture radar) sensors and different years for a Karakoram-wide coverage. High-resolution SAR data enables the investigation of small and relatively fast-flowing glaciers (e.g., up to $1.8 \mathrm{~m} \mathrm{day}^{-1}$ during an active phase of a surge). The combination of multitemporal optical imagery and SAR-based surface velocities enables an improved, Karakoram-wide glacier inventory and hence, provides relevant new observational information on the current state of glaciers in the Karakoram.
\end{abstract}

\section{Introduction}

Meltwater from snow cover and glaciers in high mountain areas is a major source for downstream water resources (Gardner et al., 2013; Kaser et al., 2010). Glaciers in the Karakoram and western Himalaya contribute to the discharge of the Indus River and its tributaries, which account for $90 \%$ of Pakistan's food production and $13 \mathrm{GW}$ of hydroelectricity (Cook et al., 2013; Qureshi, 2011). The amount of meltwater originating from the mountainous, glaciated catchment areas is 1.5 times greater than the discharge generated downstream along the Indus (Immerzeel et al., 2010). Hence, wellfounded knowledge of the extent and nature of changes in glaciers supports downstream hydrological planning and water resource management.

Investigations of glacier changes across the Hindu KushKarakoram-Himalaya mountain range revealed retreating glacier fronts since the mid-19th century (Bolch et al., 2012; Scherler et al., 2011) and negative geodetic mass balances for the entire mountain range of $-0.21 \pm 0.05 \mathrm{~m} \mathrm{a}^{-1}$ w.e. (water equivalent) between 2003 and 2008 (Kääb et al., 2012) and $-0.15 \pm 0.07 \mathrm{~m} \mathrm{a}^{-1}$ w.e. for the period 1999 to 2011 (Gardelle et al., 2013). However, mass balances for the Karakoram are found to be less negative, or even positive, using the geodetic method (Gardelle et al., 2012, 2013; Gardner et al., 2013; Kääb et al., 2012). Both stable and advancing terminus positions have been described by various authors (e.g., Bhambri et al., 2013; Bolch et al., 2012; Hewitt, 2005; Scherler et al., 2011).

The Karakoram is also known for a large number of surgetype glaciers, which have been reported since the 1860s (Barrand and Murray, 2006; Copland et al., 2011; Hewitt, 1969, 
1998, 2007; Kotlyakov et al., 2008; Mason, 1931). There has been a marked increase in surge activity in recent years (Copland et al., 2011). Surge-type glaciers are also common outside of the Karakoram, e.g., in Alaska and the Yukon, the Canadian high Arctic, Svalbard, Iceland, and the Russian high Arctic (Cuffey and Paterson, 2010). However, the mechanisms triggering surge events differ among the various regions. Surge-type glaciers are identifiable by distinctive surface features like looped and folded medial moraines, ice foliation, crevassed surfaces, and/or advancing glacier tongues (Barrand and Murray, 2006; Hewitt, 1969; Meier and Post, 1969). During the active phase of a surge, within a few months to several years, glacier surface velocities increase by at least one order of magnitude compared to nonsurging glaciers (Meier and Post, 1969). Moreover, the glacier terminus steepens and thickens throughout a surge event, as ice from the reservoir area is shifted towards the receiving area (Clarke et al., 1984; Meier and Post, 1969). The rapid advance of a glacier tongue may dam river valleys, which leads to the formation of lakes. Failure of the ice and/or moraine dams, may result in glacial-lake-outburst floods (GLOFs) endangering downstream areas. In the upper Indus Basin 71 GLOFs have been reported since the early 19th century (Hewitt, 1982, 2014; UNDP, 2013).

The present study investigates the temporal variability and spatial distribution of surge-type, advancing, stable, and retreating glaciers across the Karakoram region. Existing surge-type glacier inventories (Barrand and Murray, 2006; Copland et al., 2011; Hewitt, 1998) are updated and refined using Landsat time series (1976-2012), and a detailed analysis of termini-position changes of surge-type, advancing, and retreating glaciers since 1976 is carried out. The inventory compares dimensional and topographic characteristics of each glacier class. Centerline profiles are generated using a homogeneous procedure for the entire Karakoram. A complete coverage of glacier surface velocities is achieved from repeat, very high-resolution synthetic aperture radar (SAR) imagery as a composite in the period 2007-2011. In several case studies, we demonstrate the potential of very highresolution SAR time series to map changes in ice flow for very small surge-type or advancing glaciers, and complement this analysis with products based on archived scenes from ERS (European remote sensing satellite) SAR and Envisat ASAR (advanced synthetic aperture radar). During the active phase of a surge event, high surface velocities close to the glacier snout support the identification of surge-type glaciers.

\section{Study Site}

The Karakoram is part of the Hindu Kush-KarakoramHimalaya mountain range. It is located between the borders of India, Pakistan, Afghanistan, and China and stretches over $\sim 500 \mathrm{~km}$ in a NW to SE direction (Fig. 1). The region in- cludes four peaks higher than $8000 \mathrm{~m}$ a.s.l. (above sea level), and half of its surface lies above $5000 \mathrm{~m}$ a.s.l. (Copland et al., 2011). The glaciated area covers $\sim 17946 \mathrm{~km}^{2}$ (Bolch et al., 2012), including some of the largest glaciers outside the polar regions, e.g., Siachen Glacier $(\sim 72 \mathrm{~km}$ long $)$, Baltoro Glacier $(\sim 64 \mathrm{~km})$, and Biafo Glacier $(\sim 63 \mathrm{~km})$. The glaciers in the Karakoram extend over a wide range of elevations (from $\sim 3000$ to $>8000 \mathrm{~m}$ a.s.l.), while $60-80 \%$ of the glaciated area is found between altitudes of 3800 and $5800 \mathrm{~m}$ a.s.l. (Hewitt, 2005). For most glaciers, nourishment is mainly or wholly determined by snow avalanches, which also contribute to heavy accumulation of supraglacial debris (Hewitt, 2005).

The climate in the Karakoram is influenced by the Asian monsoon, which contributes up to $80 \%$ of the summer precipitation in the southeastern part of the Karakoram (Bolch et al., 2012). During winter, precipitation occurs predominantly due to westerly cyclones and is responsible for about twothirds of the snowfall in high altitudes (Bolch et al., 2012). Northward, the steep topography of the Karakoram and its more continental location lead to a decreasing influence of both wind systems. In the western part of the mountain range, Winiger et al. (2005) estimated average annual precipitation values of $1500-1800 \mathrm{~mm} \mathrm{a}^{-1}$ at $5000 \mathrm{ma}$ a.s.l., and considerably lower values of $\sim 600 \mathrm{~mm} \mathrm{a}^{-1}$ at $5000 \mathrm{~m}$ a.s.l. north of the Batura Glacier ( $\left.36^{\circ} 32^{\prime} \mathrm{N}, 74^{\circ} 39^{\prime} \mathrm{E}\right)$. Another study found a similar trend indicating increasing precipitation from north to south over the Hunza Basin, with average values of $1174 \mathrm{~mm} \mathrm{a}^{-1}$ at $6000 \mathrm{~m}$ a.s.l. (Immerzeel et al., 2012).

An increase in winter precipitation in the Karakoram has been observed since the early 1960s (Archer and Fowler, 2004; Bolch et al., 2012; Yao et al., 2012). Williams and Ferrigno (2010) found decreasing summer mean and minimum temperatures as well as increasing winter mean and maximum temperatures across the upper Indus Basin, which partly coincides with the studies of Bocchiola and Diolaiuti (2013) and Shekhar et al. (2010). However, it needs to be considered that most climate stations are located at low altitudes in the mountain valleys. The positive precipitation trends, decreasing summer temperatures, and the high-altitude origins of Karakoram glaciers favored positive mass balances of $+0.10 \pm 0.16 \mathrm{~m} \mathrm{a}^{-1}$ w.e. between 1999 and 2010, assuming an ice density of $850 \mathrm{~kg} \mathrm{~m}^{-3}$ for the Karakoram as observed by Gardelle et al. (2013) by differencing digital elevation models from the respective years. Another study found positive elevation difference trends in winter $\left(+0.41 \pm 0.04 \mathrm{~m} \mathrm{a}^{-1}\right)$ and only slightly negative elevation difference trends in autumn $\left(-0.07 \pm 0.04 \mathrm{~m} \mathrm{a}^{-1}\right)$ for the Karakoram, derived from ICESat (Ice, Cloud, and land Elevation Satellite) time series from 2003 to 2008/09 (Kääb et al., 2012). 


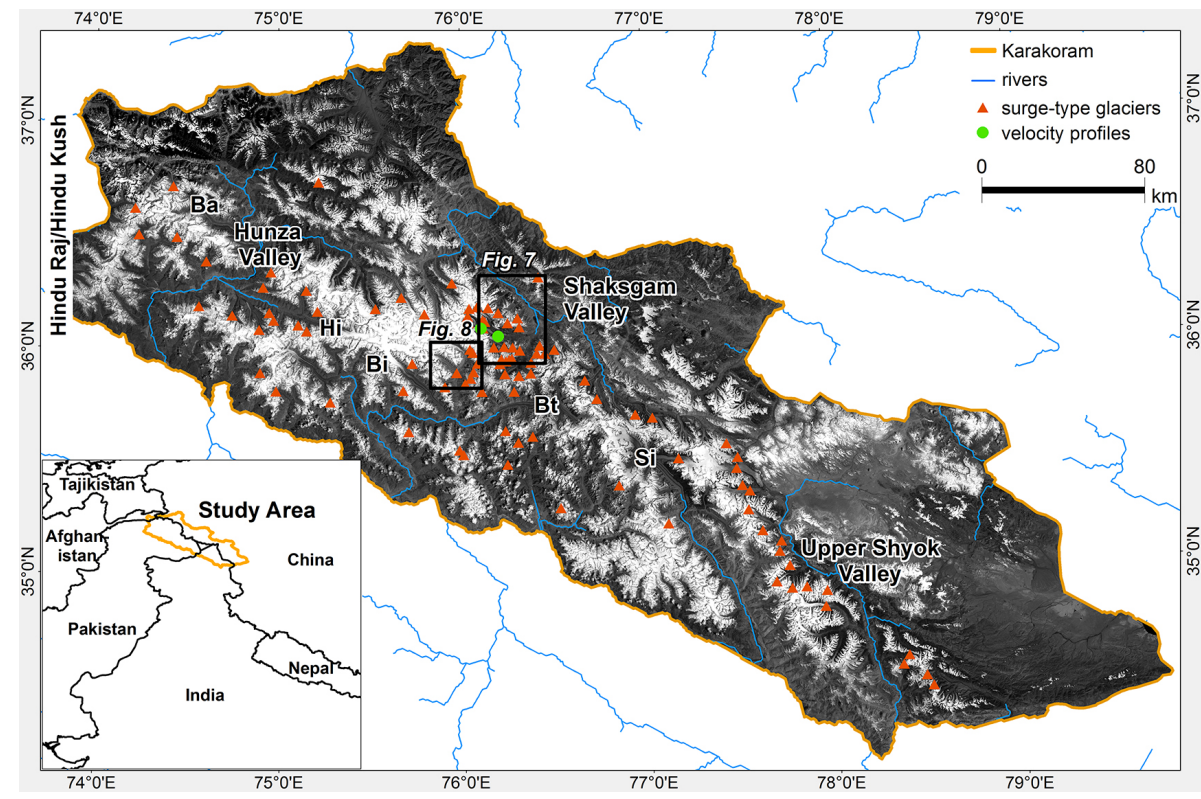

Figure 1. Overview map of the Karakoram. Surge-type glaciers are marked with red triangles. The locations of major glaciers and groups are indicated. Abbreviations: Ba - Batura Glacier, Bi - Biafo Glacier, Bt - Baltoro Glacier, Hi - Hispar Glacier, and Si - Siachen Glacier. Green dots represent the Skamri and South Skamri glaciers, for which velocity profiles are shown in the results section. Locations of Figs. 7 and 8 are outlined. Background: Landsat mosaic over 2011 ( ${ }^{\odot}$ USGS, 2011).

\section{Data and methods}

\subsection{Glacier inventory and terminus positions}

The glacier outlines in the present inventory are based on the Randolph Glacier Inventory 2.0 (RGI) (Arendt et al., 2013), which provided subdivided glacier complexes for the Karakoram region. Each glacier polygon was improved manually in accordance with the guidelines of the Global Land Ice Measurements from Space (GLIMS) (Racoviteanu et al., 2010), using cloud-free, late-summer Landsat scenes from 2009 to 2011, and the $90 \mathrm{~m}$ resolution C-band SRTM DEM (Shuttle Radar Topography Mission digital elevation model; 11-22 February 2000; http://srtm.csi.cgiar.org). We deviated from the GLIMS guidelines if tributary glaciers showed obvious surge-type behavior. Such tributaries were separated from the main trunk, and treated as individual glaciers in the database. For each glacier polygon, terminus position changes were mapped using Landsat imagery (Supplement Table S1), which allowed us to determine whether the respective glacier was advancing, stable, or retreating during the observation period 1976-2012. A terminus was classified as advancing or retreating if it changed by at least $\sim 60 \mathrm{~m}$ (exceeding the uncertainties in the digitization process of approximately two pixels). Existing inventories on surge-type glaciers, dating back to the 1860s (e.g., Barrand and Murray, 2006; Copland et al., 2011; Hewitt, 1998), were complemented by our own observations, including the identification of new surge-type glaciers that had been unknown before. These glaciers were identified by investigating their annual termini-position changes using Landsat time series between 1976 and 2012, surface velocities, surface features like crevasses, and/or terminus thickening. Within the inventory, surge-type glaciers were counted once, even if they showed more than one active phase during the study period. The subsequent analysis of each glacier class was restricted to glaciers at least $3 \mathrm{~km}$ in length and more than $0.15 \mathrm{~km}^{2}$ in area. The area threshold removed glacierets and potential snow fields from the analysis, while the length threshold removed smaller glaciers that are typically difficult to classify into surging- or nonsurging-type based on our criteria.

By combining the glacier outlines and the C-band SRTM DEM, we derived a set of parameters describing dimensional glacier characteristics. For each glacier, we calculated area, average slope, and glacier length, following the recommendations in Paul et al. (2010). The glacier-area parameter was calculated as planar area, i.e., no correction for slope was carried out. Slopes were calculated for individual grid cells by analyzing the elevations of each cell and its eight neighbors. The mean of these slopes yielded the average glacier slope. We determined glacier length by acquiring the length of the longest glacier centerline, which was picked out of a set of centerlines covering the main branches of each individual glacier.

The centerlines were compiled semiautomatically by calculating least-cost routes between glacier heads and termini following the procedure in Kienholz et al. (2014). The heads (one per glacier branch) were determined by automatically 
identifying local elevation maxima along the glacier outlines. The termini were set at the lowermost cells along the outlines. Some manual intervention was required if glacier heads were misplaced, or if the automatically derived glacier termini were not at the location of the actual termini. The leastcost route was eventually calculated on a cost grid individually prepared for each glacier and containing penalty values that decrease toward the glacier center as well as downslope. The resulting least-cost route yielded centerlines that are similar in shape to actual flow lines. The centerlines enabled the accurate determination of glacier length, derivation of average slope and aspect, and measurement of velocity along those profiles.

The SRTM DEM we used contains errors, particularly in areas with filled voids (e.g., Frey and Paul, 2012). These errors can reduce the quality of the derived inventory parameters, especially if one single DEM value exclusively determines the parameter (e.g., minimum elevation; Frey et al., 2012). However, for our statistical analysis, we rely on inventory parameters that are either not or only marginally dependent on the DEM quality. The parameter glacier area is derived from the glacier outlines directly, and thus independent of DEM quality. To derive the centerlines, and thus the parameter glacier length, we relied on the DEM in two ways. First, we used elevation maxima and minima to derive the glacier heads and termini. Second, we set up the cost grid by incorporating elevation values. While DEM errors interfere with both applications, we checked the results visually to correct implausible centerlines. Accordingly, the final glacier lengths should be largely independent of the DEM quality. Finally, the parameter mean slope is directly derived from the DEM. However, because it is an averaged value, the influence of the DEM quality is also limited here (Frey et al., 2012).

The new glacier inventory in this study provides updated dimensional characteristics for each glacier class using a homogenous methodology for the entire Karakoram. The statistical significance of the differences within the specific distributions was tested with a two-sided Wilcoxon rank-sum test (Wilcoxon, 1945).

\subsection{Glacier surface velocities}

Surface velocities were derived using offset intensity tracking on repeat SAR satellite imagery, also known as a crosscorrelation optimization procedure (Lange et al., 2007; Luckman et al., 2003; Paul et al., 2013a; Strozzi et al., 2002). Based on the image intensity, this technique tracks surface features and also the speckle pattern on a pair of coregistered, single-look complex (SLC) images from two different acquisition dates. All algorithms were executed with Gamma Remote Sensing Software. The master image was divided into rectangular windows of a given width in range and azimuth (Table 1). For each window, the corresponding patch of the slave image was determined based on the nor- malized cross-correlation between the image patches. The maxima of the 2-D correlation function defined the offsets in range and azimuth direction. Image patches were oversampled by a factor of 2 to increase the offset estimation accuracy (Werner et al., 2005). Offsets of minor confidence were excluded using a signal-to-noise ratio (SNR) threshold (Table 1). The displacement fields were finally geocoded to map coordinates with the SRTM DEM. The technique is well suited to Himalayan-style glaciers due to the presence of distinct surface structures (Luckman et al., 2007; Quincey et al., 2011).

We used TerraSAR-X stripmap (SM) mode singlepolarization data from 2009 to 2013 and ALOS (Advanced Land Observation System) PALSAR (phasedarray synthetic-aperture radar) fine-beam single-polarization (FBS) imagery from 2007 to 2009 (Supplement Tables S2 and S3). While the data takes of the TerraSAR-X imagery may be up to 3 months apart, most ALOS imagery was acquired with the standard 46-day repeat interval. ERS-1/2 SAR imagery provided coverage for 1992, 1993, 1998, and 1999 (Supplement Table S4). The complementary Envisat ASAR products were used to derive surface velocities for 2003 and 2011 (Supplement Table S4). Processing for ERS and Envisat data was done on 30/35-day repeat coverage. SAR imagery was acquired throughout the year; however, late summer/autumn acquisitions provided the most accurate results. Decorrelation is reduced due to minimized snowmelt and not yet accumulated snow. We used identical settings for the tracking algorithms for all imagery of the same sensor (Table 1).

High-resolution SAR imagery makes it possible to map velocities over shorter temporal baselines and for smaller glaciers. Generally, longer wavelengths (e.g., L band) provide more stable backscatter signals over time, thus yielding better results in the structureless accumulation zone where shorter wavelength imagery tends to decorrelate. Hence, for complete velocity coverage of the entire Karakoram, we compiled velocity measurements from the various products and sensors, giving priority in subsequent order to the highest resolution, the best SNR, and closest acquisition date.

The precision of SAR offset tracking algorithms is dependent on various system, processing, and environmental factors. These include the temporal baseline between acquisitions; glacier surface characteristics and their changes over time; spatial representation, spatial resolution, wavelength, and temporal changes of surface characteristics; displacements of the glacier in the observation time; tracking window size, step size, search radius, and co-registration accuracy. These influences are hardly quantifiable and measurable, in particular, since they vary from image pair to image pair. However, uncertainties of the specific flow fields were estimated by determining displacement values over nonmoving terrain (e.g., bedrock), excluding snow- and ice-covered areas, glaciers, river beds, and terraces. Mean velocity errors and their standard deviations $(1 \sigma)$ were calculated with 
Table 1. Overview of sensors used for velocity mapping and their main characteristics. The parameter settings for feature tracking, such as tracking window size, step size, and SNR threshold for discarding unreliable measurements, are also listed per sensor.

\begin{tabular}{llrrr}
\hline Sensor & $\begin{array}{l}\text { Sensor wavelength, } \\
\text { platform repeat cycle }\end{array}$ & $\begin{array}{r}\text { tracking window size } \\
\text { (range } \times \text { azimuth) }\end{array}$ & $\begin{array}{r}\text { Step } \\
\text { (range/azimuth) }\end{array}$ & $\begin{array}{r}\text { SNR } \\
\text { threshold }\end{array}$ \\
\hline \multirow{2}{*}{ ALOS PALSAR FBS } & $\begin{array}{l}23.5 \mathrm{~cm} \\
\text { L band } \\
46 \text { days }\end{array}$ & $64 \times 192$ & $12 / 36$ & $>7$ \\
\hline \multirow{2}{*}{ TerraSAR-X SM } & $\begin{array}{l}3.1 \mathrm{~cm} \\
\mathrm{X} \text { band } \\
11 \text { days }\end{array}$ & $128 \times 128$ & $25 / 25$ & $>7$ \\
\hline \multirow{2}{*}{ ERS-1/2 SAR } & $\begin{array}{l}5.6 \mathrm{~cm} \\
\mathrm{C} \text { band }\end{array}$ & $64 \times 320$ & $6 / 30$ & $>5$ \\
\hline & 35 days & & & \\
\hline & $\begin{array}{l}5.6 \mathrm{~cm} \\
\mathrm{C} \text { band } \\
35 / 30^{*} \text { days }\end{array}$ & $64 \times 320$ & $6 / 30$ & $>5$ \\
\end{tabular}

*30-day repeat cycle since October 2010

Table 2. Mean uncertainties of displacement fields calculated over nonmoving terrain given for each sensor and each temporal baseline (in $\mathrm{cm} \mathrm{day}^{-1} \pm 1$ standard error, s.e.).

\begin{tabular}{lrr}
\hline Sensor & $\begin{array}{r}\text { Repeat cycle } \\
(\text { days })\end{array}$ & $\begin{array}{r}\text { Mean uncertainty } \\
\left(\text { cm day }^{-1} \pm 1 \text { s.e. }\right)\end{array}$ \\
\hline TerraSAR-X SM & $11 / 22 / 143$ & $1.9 \pm 5.0 / 1.3 \pm 4.0 / 0.4 \pm 1.0$ \\
ALOS PALSAR FBS & 46 & $2.9 \pm 9.0$ \\
ERS-1/2 SAR & 35 & $7.5 \pm 9.0$ \\
Envisat ASAR & $35 / 30^{*}$ & $2.2 \pm 3.0$ \\
\hline
\end{tabular}

*30-day repeat cycle since October, 2010.

10000 random samples over stable ground for each image pair and each temporal baseline (Table 2).

\section{Results and discussion}

\subsection{Glacier inventory and terminus positions}

The analysis of the Landsat time series revealed a large number of stable glaciers (969), 56 advancing, and only 93 retreating glaciers out of 1219 glaciers in the inventory during the observation period of 1976-2012. A total of 101 glaciers in the inventory were once or multiple times in the active phase of a surge since the 1860s. Of these, 91 have already been reported in Copland et al. (2011) and by various other authors (e.g., Barrand and Murray, 2006; Diolaiuti et al., 2003; Hewitt, 1998, 2007; Mayer et al., 2011; Quincey et al., 2011). We observed 10 more glaciers that showed an active phase of a surge during the observation period (Table 3). They indicated remarkable frontal advances of up to $\sim 3.5 \mathrm{~km}$ during a 5-year time span, increased surface ve- locities close to the glacier snout (see Section. 4.2), and/or looped/folded medial moraines (Table 3). Ten of the 101 surge-type glaciers counted were still in the active phase in 2012.

In a previous study, Barrand and Murray (2006) analyzed potential morphometric and environmental factors influencing glacier surges, based on 150 glaciers, of which 19 were surge-type glaciers. Within the present inventory, we can rely on a much larger database (1219 glaciers) over a longer time period (1976-2012). Characteristics of surge-type (101), advancing (56), retreating (93), and stable (969) glaciers, such as the glacier length, the area of the glacier catchment, and the mean slope of the main glacier branch were compared. The length, area and slope distributions of the different glacier classes (Fig. 2) differed significantly $(p<0.0001)$ referring to a Wilcoxon rank-sum test. The minimum glacier length of each glacier class was fixed by a threshold of $3 \mathrm{~km}$. Glaciers below this threshold were not considered in the statistical analysis. The maximum length varied between $\sim 28.4 \mathrm{~km}$ (median $=6.2 \mathrm{~km}$ ) for advancing, $\sim 45.6 \mathrm{~km}$ (median $=11.3 \mathrm{~km}$ ) for surge-type, $\sim 57.2 \mathrm{~km}$ (median $=5.1 \mathrm{~km}$ ) for retreating, and $\sim 75.8 \mathrm{~km}$ (median $=4.4 \mathrm{~km}$ ) for stable glaciers. The median length distribution is strongly influenced by the high number of glaciers smaller than $10 \mathrm{~km}$ in length (Fig. 2a) and by the lower length limit (i.e., $3 \mathrm{~km}$ ) of our analysis. Figure $2 \mathrm{a}$ demonstrates that approximately $90 \%$ of each type - advancing, stable and retreating glaciers - are smaller than $10 \mathrm{~km}$ in length. Surge-type glaciers are, in general, longer than advancing, retreating, and stable glaciers (two-thirds of surge-type glaciers $>10 \mathrm{~km}$ long). The length distribution is comparable with that found by Barrand and Murray (2006), 
Table 3. New surge-type glaciers identified in this study. Surge-type features include (1) looped/folded medial moraines and surface foliation, (2) terminus advance, (3) terminus steepening and thickening, and (4) increased surface velocities (according to Copland et al., 2011).

\begin{tabular}{|c|c|c|c|c|c|c|c|c|}
\hline $\begin{array}{l}\text { Glacier } \\
\text { name }\end{array}$ & Lat & Long & $\begin{array}{l}\text { Mean elevation } \\
(\mathrm{m})\end{array}$ & $\begin{array}{l}\text { Length } \\
(\mathrm{km})\end{array}$ & $\begin{array}{l}\text { Area } \\
\left(\mathrm{km}^{2}\right)\end{array}$ & $\begin{array}{l}\text { Date of } \\
\text { active phase }\end{array}$ & $\begin{array}{l}\text { Detected surge-type } \\
\text { features }\end{array}$ & $\begin{array}{l}\text { Catchments } \\
\text { in Fig. } 7\end{array}$ \\
\hline Unnamed & 35.924 & 76.374 & 5829.0 & 6.01 & 8.58 & $2005-13$ & (2), (4), advance of $\sim 500 \mathrm{~m}$ & 15 \\
\hline Unnamed & 35.965 & 76.405 & 5379.5 & 5.47 & 3.20 & $2002-11$ & (2), (4), advance of $\sim 500 \mathrm{~m}$ & 14 \\
\hline Unnamed & 35.993 & 76.275 & 5215.0 & 6.30 & 4.37 & $2002-10$ & (1), (2), (4), advance of $\sim 2 \mathrm{~km}$ & 12 \\
\hline Unnamed & 35.999 & 76.423 & 5086.0 & 6.12 & 3.26 & $2002-11$ & (2), (4), advance of $\sim 1.3 \mathrm{~km}$ & 13 \\
\hline Unnamed & 36.082 & 76.312 & 5599.0 & 9.69 & 11.35 & $2002-13$ & (2), (4), advance of $\sim 1.5 \mathrm{~km}$ & 7 \\
\hline Unnamed & 36.101 & 76.249 & 5484.5 & 5.35 & 2.93 & $2011-13$ & (2), (4), advance of $\sim 1 \mathrm{~km}$ & 9 \\
\hline Unnamed & 36.123 & 76.303 & 5548.0 & 8.33 & 12.75 & $2001-13$ & (1), (2), (4), advance of $\sim 800 \mathrm{~m}$ & 6 \\
\hline Unnamed & 36.146 & 76.198 & 5554.0 & 16.37 & 26.16 & $2009-13$ & (2), (4), advance of $\sim 3.5 \mathrm{~km}$ & 4 \\
\hline Saxinitulu & 36.280 & 75.947 & 5553.5 & 16.14 & 27.09 & $2001,2011-13$ & (2), (4), advance of $\sim 900 \mathrm{~m}$ in total & not shown \\
\hline Unnamed & 36.730 & 75.219 & 5440.0 & 7.52 & 9.09 & $2003-05$ & $(1),(2)$, advance of $\sim 800 \mathrm{~m}$ & not shown \\
\hline
\end{tabular}

a)

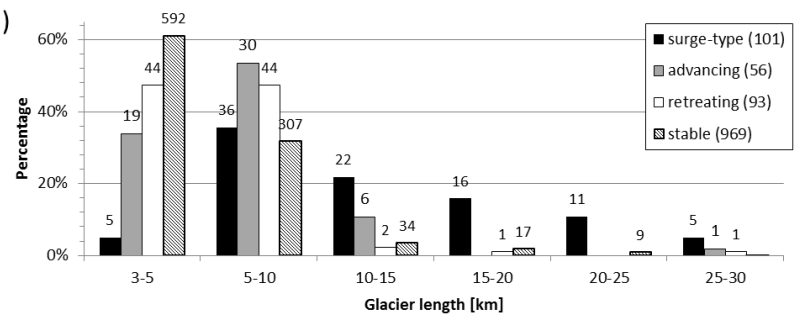

b)

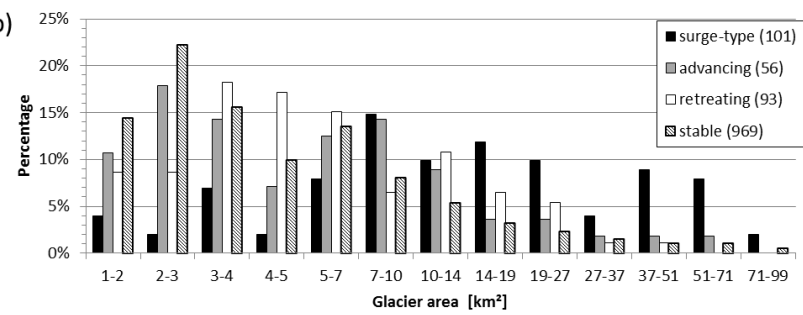

c)

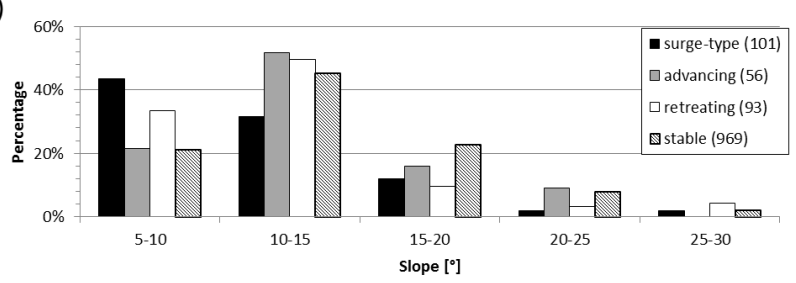

Figure 2. Percentage of glaciers classified as surge-type, advancing, retreating, or stable during the observation period 1976-2012, related to the overall number of each class, divided into (a) glacier length, (b) catchment area, and (c) mean slope along the main glacier branch. The absolute numbers per glacier length class are given above the bars in panel (a).

who observed a peak in the length distribution of surge-type glaciers at $10 \mathrm{~km}$ (median $=13.6 \mathrm{~km})$.

The histogram of the glacier area (Fig. 2b) shows that surge-type glaciers have larger areas $\left(\right.$ median $=15.3 \mathrm{~km}^{2}$ ) than advancing $\left(\right.$ median $\left.=4.4 \mathrm{~km}^{2}\right)$, stable (median = $3.8 \mathrm{~km}^{2}$ ), and retreating $\left(\right.$ median $=4.9 \mathrm{~km}^{2}$ ) glaciers in the inventory. This pattern matches the length distribution of the individual glacier classes. Half of the stable glaciers and $45 \%$ of the advancing glaciers are less than $4 \mathrm{~km}^{2}$. More than $50 \%$ of retreating glaciers are between 3 and $7 \mathrm{~km}^{2}$. The analysis of the mean slope along the main glacier branch allows no significant differentiation between the glacier classes (Fig. 2c). Most glaciers have only slightly inclined surfaces $\left(15^{\circ}\right)$. Surge-type glaciers are less inclined $\left(\right.$ median $\left.=9.6^{\circ}\right)$; however, the slope of a glacier does not correlate significantly with the glacier type.

Figure 3 illustrates the spatial distribution of glaciers classified as surge-type, advancing, retreating or stable across the Karakoram. Surge-type glaciers are mostly located in the Sarpo Laggo Basin, the Shaksgam Valley, the Panmah Basin, and at the eastern part of the Karakoram along the upper Shyok River (Figs. 1, 3; Table 3). Advancing glaciers partly cover the same glacier basins as surge-type glaciers do (e.g., north-western margins of the Shaksgam Valley). However, there is no marked clustering evident. The largest glaciers in the Karakoram, such as the Siachen, Baltoro, Biafo, and Chogo Lungma glaciers, show rather stable, heavily debriscovered termini during the observation period, as other studies also confirmed (Hewitt, 2005; Mayer et al., 2006). However, termini-position changes are hard to quantify for debriscovered glaciers (Paul et al., 2013b). They are also ambiguous reactions of these glaciers to changing climatic conditions and should be confirmed with mass-balance studies (Scherler et al., 2011). Retreating glaciers, mostly small, are mainly located at the eastern margins of the Karakoram, north of the Shimshal River and west of the Hunza River close to the Hindu Raj mountains (Fig. 3).

The large number of stable glacier termini and glacier advances is influenced by positive glacier-mass balances in the central Karakoram during the last decade (Gardelle et al., 2012, 2013; Kääb et al., 2012) induced by increasing winter precipitation and decreasing summer temperatures since the 1960s (Archer and Fowler, 2004; Bocchiola and Diolaiuti, 2013; Bolch et al., 2012; Williams and Ferrigno, 2010; 


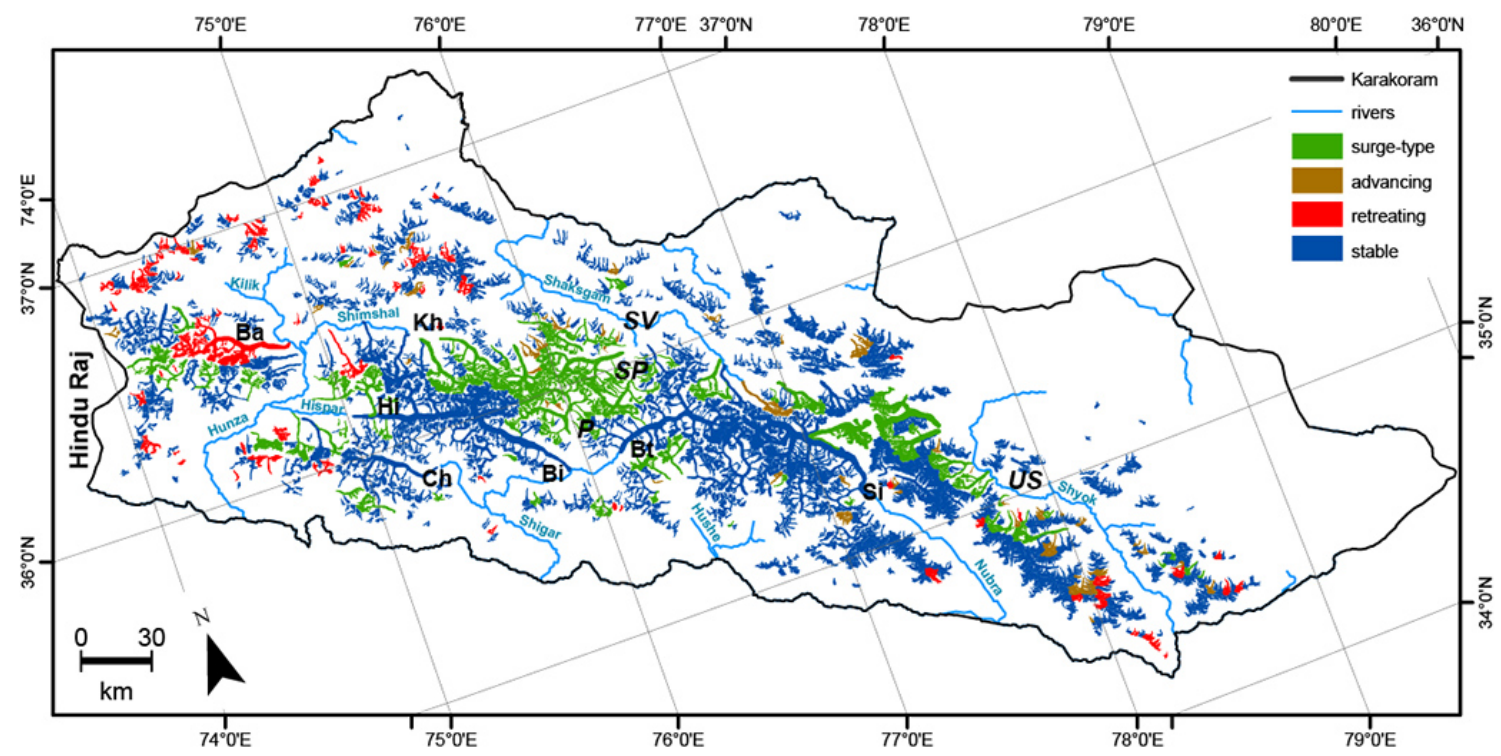

Figure 3. Spatial distribution of glaciers classified as surge-type, advancing, retreating, or stable across the Karakoram during the observation period 1976-2012. Abbreviations: Ba - Batura Glacier, Bi - Biafo Glacier, Bt - Baltoro Glacier, Ch - Chogo Lungma Glacier, Hi - Hispar Glacier, Kh - Khurdopin Glacier, Si - Siachen Glacier, P - Panmah Basin, SP - Sarpo Laggo Basin, SV - Shaksgam Valley, and US - upper Shyok Valley.

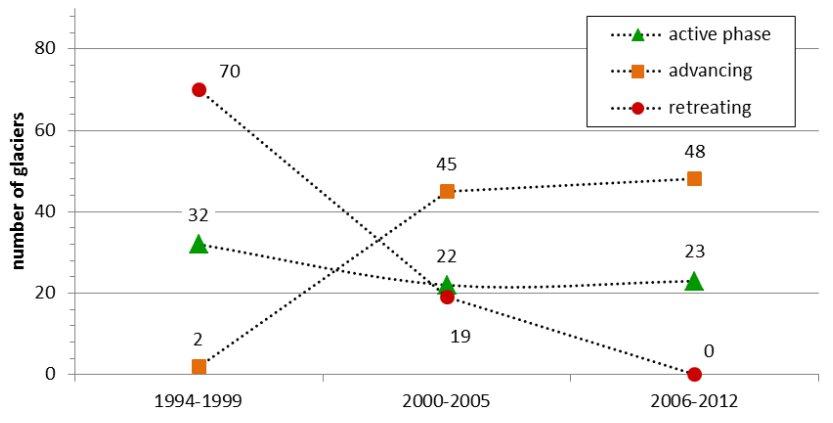

Figure 4. Temporal course of advancing and retreating glaciers, as well as glaciers in the active phase of a surge during various time periods. Glaciers were counted repeatedly if advancing, retreating, or active in various time periods.

Yao et al., 2012). In contrast, adjacent mountain ranges (Himalaya, the western Kunlun Shan, Hindu Kush, and Hindu Raj) are mainly affected by negative glacier-mass balances and glacier recession (e.g., Bolch et al., 2012; Sarikaya et al., 2012, 2013; Scherler et al., 2011). Various authors found that $\sim 70 \%$ of glaciers retreated in the Hindu Raj and Hindu Kush mountains west of the Karakoram between the 1970s and 2007 (Sarikaya et al., 2012, 2013; also: Scherler et al., 2011). Studies also show negative mass balances in this area between 1999 and $2008\left(-0.12 \pm 0.16 \mathrm{~m} \mathrm{a}^{-1}\right.$ w.e. (assumed ice density $850 \mathrm{~kg} \mathrm{~m}^{-3}$ ); Gardelle et al., 2013) and between 2003 and $2009\left(-0.19 \pm 0.06 \mathrm{~m} \mathrm{a}^{-1}\right.$ w.e. (assumed ice density $900 \mathrm{~kg} \mathrm{~m}^{-3}$ ); Kääb et al., 2012). East of the Karakoram, glacier recession is also very common for the western $(87 \%$ of glaciers retreating) and central Himalaya (north: $83 \%$, south: $65 \%$ of glaciers retreating; Scherler et al., 2011). Mass balances are found to be more negative across the Himalaya (western and central Himalaya: $-0.34 \pm 0.05 \mathrm{~m} \mathrm{a}^{-1}$ w.e., eastern Himalaya: $-0.34 \pm 0.08 \mathrm{~m} \mathrm{a}^{-1}$ w.e. between 2003 and 2009 assuming an ice density of $900 \mathrm{~kg} \mathrm{~m}^{-3}$; Kääb et al., 2012; Gardelle et al., 2013) in comparison to the Karakoram $\left(-0.06 \pm 0.04 \mathrm{~m} \mathrm{a}^{-1}\right.$ w.e. (assumed ice density $\left.900 \mathrm{~kg} \mathrm{~m}^{-3}\right)$; Kääb et al., 2012). However, these trends in glacier behavior seem to also affect glaciers in the northwestern part of the Karakoram, where various glaciers are retreating (Fig. 3). Decreasing high-altitude precipitation in the northern part of the Karakoram and towards the Hindu Kush mountains in comparison to the central part of the Karakoram might be one influencing factor for glacier recession (Weiers, 1993). Few retreating glaciers can also be found at the southeastern margins of the Karakoram (Fig. 3).

Figure 4 shows the varying numbers of advancing, retreating, and surge-type glaciers in the active phase since 1994, identified from Landsat imagery. The number of retreating glaciers decreased over time, whereas termini advances happened more frequently since 2000 (Fig. 4). Between 2006 and 2012 no retreating glaciers were found; however, glacier advances continued. Retreating and thinning glaciers in the Karakoram until 1997 are mentioned in Hewitt (2005). Additionally, glacier thickening and advances at glaciers larger than $10 \mathrm{~km}$ and at the highest watersheds have been reported since then (Hewitt, 2005). Other studies have found stable and positive glacier-mass balances since 1999 (Gardelle et 


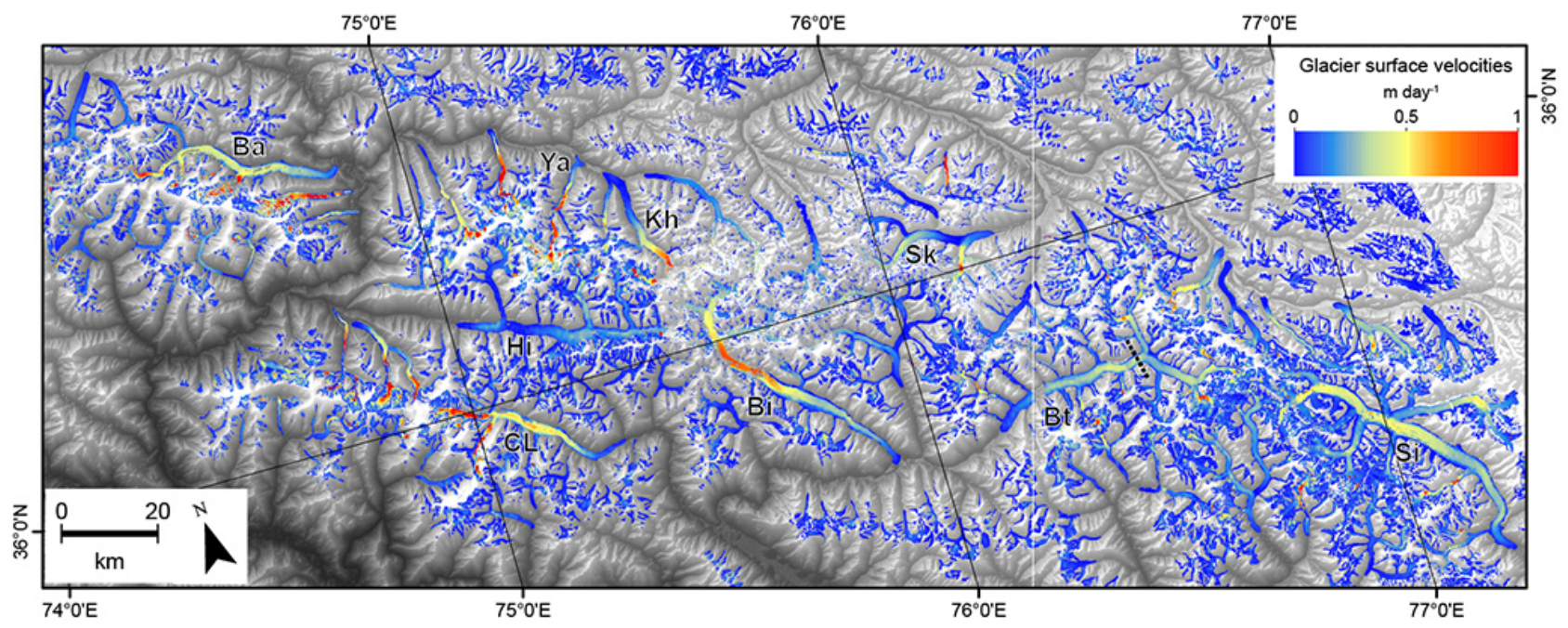

Figure 5. Compiled surface velocities mosaic of the Karakoram. Priority has been given to the highest resolution and best coverage. Data takes are between 2007 and 2011 from TerraSAR-X, ALOS PALSAR, and Envisat ASAR. The dashed line at Baltoro Glacier marks the Concordia cross profile mentioned in the text. Abbreviations: Ba - Batura Glacier, Bi - Biafo Glacier, Bt - Baltoro Glacier, CL - Chogo Lungma Glacier, Hi - Hispar Glacier, Khv - ,Khurdopin Glacier, Si - Siachen Glacier, Sk - Skamri Glacier, Ya - Yazghil Glacier. Background: SRTM DEM. Higher resolved subsets are shown in the Supplement (Figs. S2-S4).

al., 2012, 2013; Kääb et al., 2012). However, mass balance measurements prior to 1997 are not available.

Jóhannesson et al. (1989) supposed glacier response times for typical glaciers (thicknesses between 100 and $500 \mathrm{~m}$ ) to range between 10 and 100 years. For the large number of small Karakoram glaciers (90\% of nonsurge-type glaciers $<10 \mathrm{~km}$ ), of which low thicknesses can be assumed, we therefore suggest short response times of about 10-20 years. Considering increasing precipitation in winter and decreasing summer mean and minimum temperatures across the upper Indus Basin since the 1960s (Archer and Fowler, 2004; Bocchiola and Diolaiuti, 2013, Fowler and Archer, 2006; Williams and Ferrigno, 2010; Yao et al., 2012) and short response times of small glaciers, we suggest a shift from negative to balanced/positive mass budgets in the 1980s or 1990s or even earlier. For larger glaciers we expect a time-delayed reaction with stable or advancing termini in the late 1990s or years since 2000 .

The decreasing number of surge-type glaciers in an active surge phase over time is difficult to explain. There are no obvious reasons that would explain such a change in frequency since mechanisms driving surge behavior are complex and yet not fully understood and vary in different regions (Belò et al., 2008). One influencing factor might be positive glacier-mass balances in the Karakoram since 1999 (Clarke et al., 1984; Copland et al., 2011). However, changes in mass balances might be insufficient, and further changes in the thermal regime of a surge-type glacier need to occur or more meltwater needs to become available to influence surge incidences (Harrison and Post, 2003; Hewitt, 2007). In addition to climate and geometric characteristics of surge-type glaciers, the geological setting of the glacier bed plays an important role in triggering surges (Clarke et al., 1984; Harrison and Post, 2003; Murray et al., 2003). For the Karakoram, there are no comprehensive in situ studies on surge-type glaciers during active phases available that would allow constraining the number of influencing factors.

\subsection{Glacier surface velocities}

Surface velocity maps were derived from different sensors for the years 1992, 1993, 2003, and 2006-2013. Figure 5 provides the best velocity coverage (2007-2011) for the Karakoram derived from different sensors, with priority given to the highest resolution and best coverage for each individual glacier. Large-swath sensors like ERS and Envisat provide high spatial coverage at one time interval; however, they do not allow for the derivation of displacement rates for small glaciers. The latter are best resolved with TerraSAR-X imagery, but lead to a combination of different time steps. Although the suitability of such a composite velocity map is limited for glaciers with temporally highly variable ice flow (e.g., Mayer et al., 2006; Quincey et al., 2009a; Scherler and Strecker, 2012), it provides an overview of the entire region with maximum spatial detail, and is relevant for many other glaciers showing less dynamic behavior. Higherresolved subsets of the derived flow fields are available in the Supplement (Figs. S2-S4). Velocity fields of very large glaciers, such as the Batura, Hispar, Biafo, Chogo Lungma, Baltoro or Siachen glaciers, can be well identified (Fig. 5). The general flow pattern is as to be expected for mountain glaciers, indicating increasing velocities upstream with highest velocities close to the equilibrium line altitude (Copland 
et al., 2009; Cuffey and Paterson, 2010; Quincey et al., 2009a, b). Flow speeds of the Baltoro Glacier are similar to those averaged over 2003-2008 in Quincey et al. (2009a). For this glacier, Mayer et al. (2006) observed highest velocities close to the Concordia cross profile using GPS measurements taken in summer 2004 (marked in Fig. 5). The present study also found high velocities of $\sim 0.5 \mathrm{~m} \mathrm{day}^{-1}$ at this part of the glacier in August 2011, derived from Envisat ASAR feature tracking. Scherler and Strecker (2012) found the highest velocities at the Biafo Glacier at about $45 \mathrm{~km}$ from the terminus, which matches the flow pattern in Fig. 5. Notably, the Hispar Glacier has the lowest surface velocities of all the very large glaciers, with speeds decreasing close to zero at the lowest third of the glacier. Pronounced high surface velocities can be observed close to the terminus in various smaller glaciers (e.g., Saxinitulu, glacier \#4; see also Supplement Figs. S1-S4), where ongoing surges have been reported previously (e.g., Tatulu Gou Glacier; Quincey et al., 2011) or are shown in this study (e.g., first Feriole Glacier, glaciers in the Shaksgam Valley and Sarpo Laggo Basin; Figs. 6,7). Detailed investigations of seasonal and interannual ice flow variations of large valley glaciers are beyond the main scope of this study.

In the Shaksgam Valley, Skamri Basin, and Sarpo Laggo Basin, we found eight surge-type glaciers that were previously unknown as such (Fig. 6, Table 3). The potential of high-resolution TerraSAR-X imagery to map ice dynamics of very narrow glaciers becomes obvious from catchments \#1, \#3, \#6, \#7, \#9, \#13, \#14,\#15, \#16, or \#17 (Fig. 6). The comparably high flow speeds throughout the glaciers or at the terminus indicate an active phase of a surge. This corresponds neatly with the mapped frontal position changes (Supplement Fig. S5). Quincey et al. (2011) showed a similar pattern of high flow velocities at the surge front of the Kunyang Glacier (a tributary of the Hispar Glacier). A nice example of a small surge-type glacier is the Musita Glacier (\#17), which revealed high surface velocities of $\sim 0.5 \mathrm{mday}^{-1}$ (JuneSeptember 2009) during the active surge phase close to its snout. The analysis of the optical imagery indicated a frontal advance of $\sim 0.85 \mathrm{~km}$ from 2005 to 2009 .

In the Panmah Basin southwest of the Shaksgam Valley, five glaciers showed surge-type behavior in the past (Nobande Sobonde, Drenmang, Chiring, Maedan, and Shingchukpi glaciers, Fig. 7a) (Hewitt, 2007; Copland et al., 2011), whereas the first Feriole Glacier is currently in the active phase of a surge (Fig. 7c, d). By March 2012, it had advanced $\sim 2.0 \mathrm{~km}$ (Fig. 7c). Flow fields derived from TerraSAR-X SM image pairs for a 22-day interval between December 2009 and January 2010 indicated high surface velocities of $\sim 1.25 \mathrm{~m} \mathrm{day}^{-1}$ near the glacier's snout (Fig. 7b). In March 2011, surface velocities increased up to $\sim 1.78 \mathrm{~m} \mathrm{day}^{-1}$ and decreased slightly in June 2013 (Fig. 7b, d). The shapes of the centerline surface velocity profiles indicate the location of the surge front close to the terminus (Fig. 7d). The surge front seemed to remain $\sim 1 \mathrm{~km}$ from the

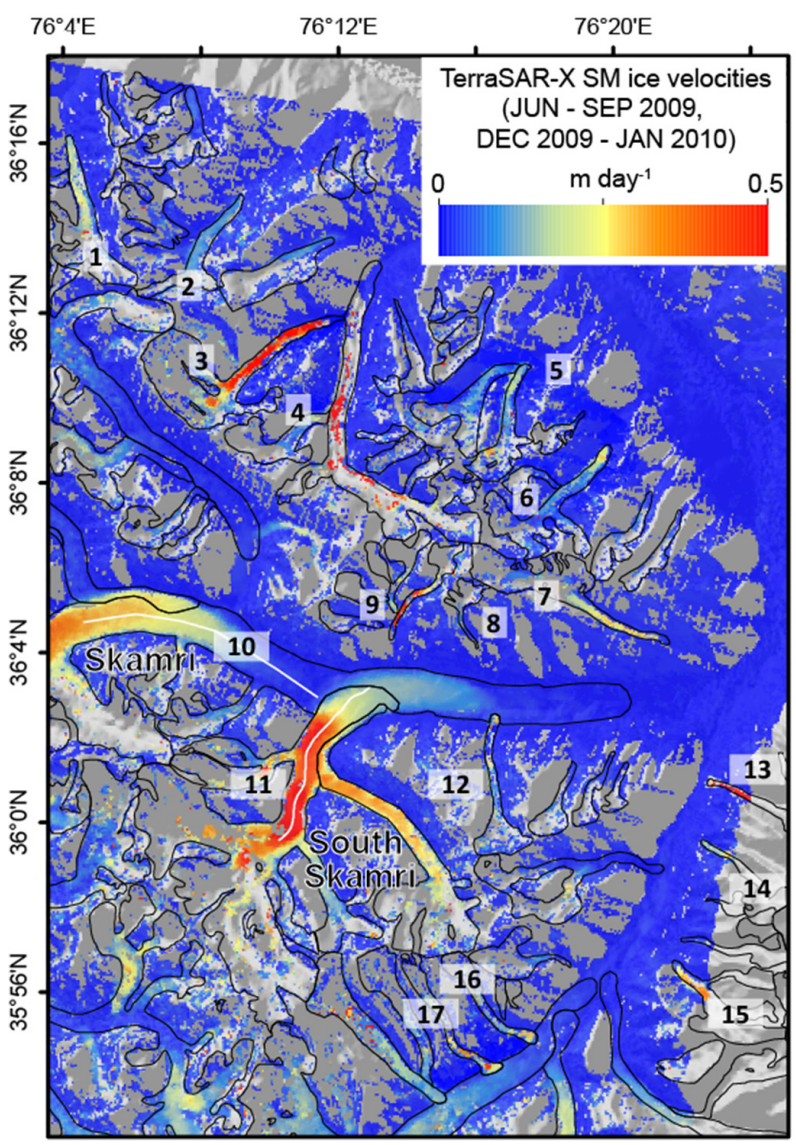

Figure 6. Surface velocities derived from TerraSAR-X SM image pairs (16 June-12 September 2009 and 24 December 2009-15 January 2010) in the central Shaksgam Valley, Sarpo Laggo and Skamri basins. Numbers indicate glacier catchments mentioned in the text and in Table 3. The centerlines of the Skamri and South Skamri glaciers are marked as white lines. Background: SRTM DEM.

terminus, though the glacier was advancing between March 2011 and June 2013. The recent decrease in surface velocities might indicate the decay of the active surge phase.

Centerline velocity profiles (Fig. 8) showed changes in surface flow over time for two surge-type glaciers (the location of these glaciers is marked in Fig. 1). The South Skamri Glacier surged in 1990 (\#11 in Fig. 6) and again in 2007 (Copland et al., 2009, 2011; Jiang et al., 2012). In 2009 it still showed high surface velocities (Fig. 8a), which are comparable to those averaged over the period 2007-2008 in Jiang et al. (2012). Surface velocities for the Skamri Glacier (\#10 in Fig. 6) decreased between 2003 and 2009 (by as much as $0.3 \mathrm{~m} \mathrm{day}^{-1}$, Fig. 8a), which supports the fact that the South Skamri Glacier was the dominant flow unit in the Skamri Basin at that time (Copland et al., 2009). During 2011 the Skamri Glacier accelerated considerably to $\sim 1.5 \mathrm{~m} \mathrm{day}^{-1}$, whereas the South Skamri Glacier slowed down slightly between 2009 and 2011. This indicates that the Skamri Glacier might be in an active surge phase again and, therefore, might 

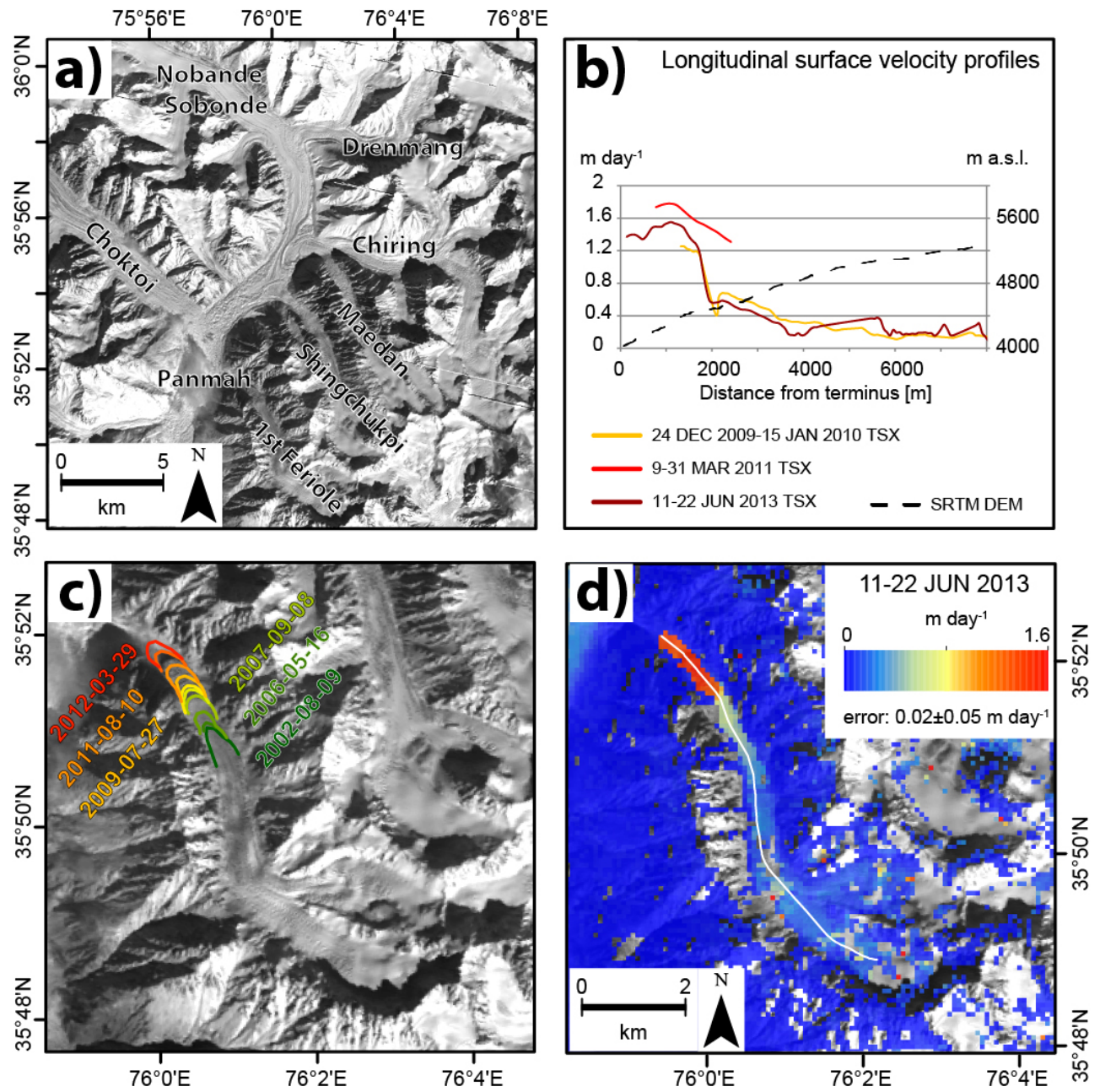

Figure 7. Termini advances and surface velocities for the first Feriole Glacier, Panmah Basin (a). Panel (b) comprises the centerline velocity profiles and their changes over time (location of the profiles is marked in (d)). Panel (c) shows the changing terminus positions since 2002. A surface velocity map derived from repeat TerraSAR-X SM imagery between 11 and 22 June 2013 is given in (d). Background: Landsat TM, 15 January 2011, ( ${ }^{\circledR}$ USGS, 2011).

influence the South Skamri Glacier again in years to come, as it did prior to 1990 .

\section{Conclusions and outlook}

The present study utilizes different remote sensing-based methods to generate an updated glacier inventory for the entire Karakoram region. It provides a new comprehensive dataset on the state of advancing, stable, and retreating glaciers, including the temporal and spatial variations of frontal positions between 1976 and 2012. Out of 1219 glaciers in the inventory, the vast majority showed stable terminus positions (969). These findings support the assumption of the anomalous behavior of glaciers in the Karakoram in comparison to adjacent mountain ranges, which indicate glacier recession and thinning (Bolch et al., 2012; Hewitt,
2005; Gardelle et al., 2013; Kääb et al., 2012; Scherler et al., 2011). Glacier recession is found for only $8 \%$ of the glaciers in the inventory, indicating decreasing numbers since the beginning of the 21 st century, whereas the number of advancing glaciers has increased since then. Considering the advance of small glaciers with assumed short response times of about 10-20 years, we conclude on a balanced/positive mass balance in the Karakoram since the 1980s or 1990s, or even earlier, induced by changing climatic conditions since the 1960s (Archer and Fowler, 2004; Bocchiola and Diolaiuti, 2013; Williams and Ferrigno, 2010; Yao et al., 2012).

Existing inventories of surge-type glaciers are updated and previously unknown surging glaciers are identified (e.g., in the Shaksgam Valley). We demonstrate the suitability of surface velocities derived from high-resolution SAR images to support the identification and analysis of surge-type glaciers. However, the complex mechanisms driving surge-type 

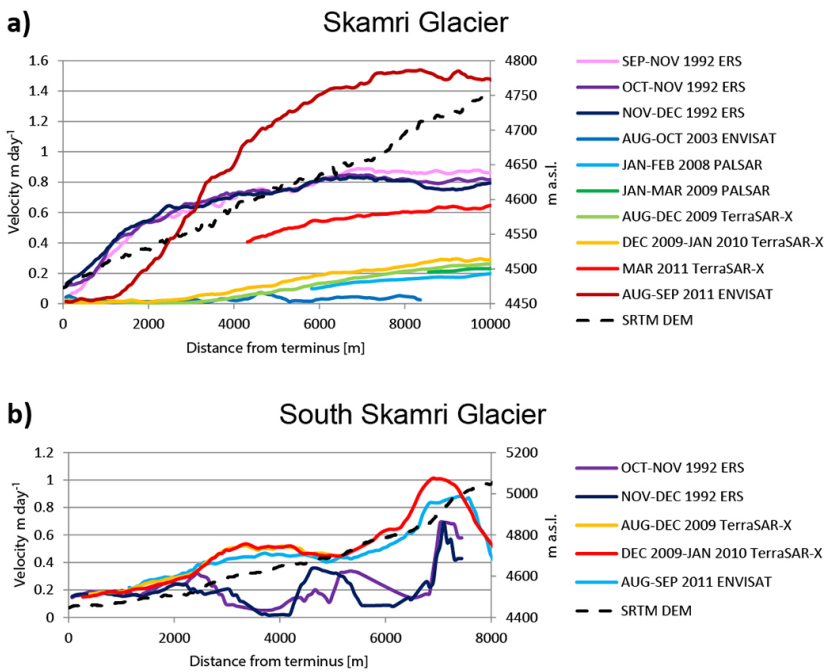

Figure 8. Velocity profiles along the centerlines of the Skamri (a) and South Skamri glaciers (b). The location of the centerline profiles is marked in Fig. 6.

behavior cannot be explained by statistical/satellite-imagery analysis alone. In particular, comprehensive field surveys would be required to gain more insight into mechanisms and driving forces of surges in this region.

Our results demonstrate the high potential modern highresolution SAR missions have for deriving surface velocity fields, including those for small and comparably fast-flowing valley glaciers during the active phase of a surge event. Short repeat cycles of 11 or 22 days enable the identification of surface structures with only a limited temporal decorrelation impact. Specific acquisition planning enables typical difficulties of active side-looking radar instruments, like layover or foreshortening, to be overcome. The study on ice dynamics also confirmed that X-band SAR, with its shorter wavelength, does decorrelate rapidly in the structureless accumulation zone of the Karakoram, where longer wavelengths (e.g., from L-band ALOS PALSAR) still preserve the signal over 46 days. It is recommended that at least annual repeat acquisitions with short temporal baselines be integrated into the acquisition plans of current and future SAR missions for regions with highly dynamic and fast-changing glaciers such as in the Karakoram. The exploitation of the satellite archives (e.g., ERS, Envisat, Landsat) provides additional potential for determining seasonal and interannual changes in flow patterns and surge cycles, which is important for monitoring glaciers in remote and inaccessible regions such as the Karakoram.

For future studies, we suggest expanding the present glacier inventory and linking it with other observational data such as surface elevation changes. Integration of the few local observations with products from regional climate models will support a more comprehensive analysis of climatic driving forces on glacier behavior.

\section{The Supplement related to this article is available online at doi:10.5194/tc-8-977-2014-supplement.}

Acknowledgements. This study was kindly supported with TerraSAR-X and TanDEM-X data under DLR AOs LAN_0164 and mabra_XTI_GLAC0264. Envisat ASAR and ERS-1/2 SAR imagery were accessed under ESA AO 3575. The USGS kindly granted access to the Landsat image archive. M. Rankl was financially supported by the University of Erlangen-Nuremberg, by the DFG Priority Program Antarctic Research, project nr. BR2105/8-1. C. Kienholz was supported by the NASA grants \#NNX11AF41G and \#NNX11AO23G. We further acknowledge support by DFG and University of Erlangen-Nuremberg within the funding program Open Access Publishing.

Edited by: A. Kääb

\section{References}

Archer, D. R. and Fowler, H. J.: Spatial and temporal variations in precipitation in the Upper Indus Basin, global teleconnections and hydrological implications, Hydrol. Earth Syst. Sci., 8, 47-61, doi:10.5194/hess-8-47-2004, 2004.

Arendt, A., Bolch, T., Cogley, J. G., Gardner, A., Hagen, J.-O., Hock, R., Kaser, G., Pfeffer, W. T., Moholdt, G., Paul, F., Radić, V., Andreassen, L., Bajracharya, S., Barrand, N., Beedle, M., Berthier, E., Bhambri, R., Bliss, A., Brown, I., Burgess, D., Burgess, E., Cawkwell, F., Chinn, T., Copland, L., Davies, B., De Angelis, H., Dolgova, E., Filbert, K., Forester, R. R., Fountain, A., Frey, H., Giffen, B., Glasser, N., Gurney, S., Hagg, W., Hall, D., Haritashya, U. K., Hartmann, G., Helm, C., Herreid, S., Howat, I., Kapustin, G., Khromova, T., Kienholz, C., König, M., Kohler, J., Kriegel, D., Kutuzov, S., Lavrentiev, I., Le Bris, R., Lund, J., Manley, W., Mayer, C., Miles, E., Li, X., Menounos, B., Mercer, A., Mölg, N., Mool, P., Nosenko, G., Negrete, A., Nuth, C., Pettersson, R., Racoviteanu, A., Ranzi, R., Rastner, P., Rau, F., Raup, B., Rich, J., Rott, H., Schneider, C., Seliverstov, Y., Sharp, M., Sigurðsson, O., Stokes, C., Wheate, R., Winsvold, S., Wolken, G., Wyatt, F., Zheltyhina, N: Randolph Glacier Inventory [v2. 0]: A Dataset of Global Glacier Outlines, Global Land Ice Measurements from Space, Boulder, Colorado, USA, Digital Media, 2013.

Barrand, N. and Murray, T.: Multivariate controls on the incidence of glacier surging in the Karakoram Himalaya, Arct. Antarct. Alp. Res., 38, 489-498, 2006.

Belò, M., Mayer, C., Smiraglia, C., and Tamburini, A.: The recent evolution of Liligo glacier, Karakoram, Pakistan, and its present quiescent phase, Ann. Glaciol., 48, 171-176, 2008.

Bhambri, R., Bolch, T., Kawishwar, P., Dobhal, D. P., Srivastava, D., and Pratap, B.: Heterogeneity in glacier response in the upper Shyok valley, northeast Karakoram, The Cryosphere, 7, 13851398, doi:10.5194/tc-7-1385-2013, 2013.

Bocchiola, D. and Diolaiuti, G.: Recent (1980-2009) evidence of climate change in the upper Karakoram, Pakistan, Theor. Appl. Climatol., 113, 611-641, 2013. 
Bolch, T., Kulkarni, A., Kääb, A., Huggel, C., Paul, F., Cogley, J. G., Frey, H., Kargel, J. S., Fujita, K., and Scheel, M.: The State and Fate of Himalayan Glaciers, Science, 336, 310-314, 2012.

Clarke, G., Collins, S., and Thompson, D.: Flow, thermal structure, and subglacial conditions of a surge-type glacier, Can. J. Earth Sci., 21, 232-240, 1984.

Cook, E. R., Palmer, J. G., Ahmed, M., Woodhouse, C. A., Fenwick, P., Zafar, M. U., Wahab, M., and Khan, N.: Five centuries of Upper Indus River flow from tree rings, J. Hydrol., 486, 365-375, 2013.

Copland, L., Pope, S., Bishop, M., Shroder, J., Clendon, P., Bush, A., Kamp, U., Seong, Y., and Owen, L.: Glacier velocities across the central Karakoram, Ann. Glaciol., 50, 41-49, 2009.

Copland, L., Sylvestre, T., Bishop, M., Shroder, J., Seong, Y., Owen, L., Bush, A., and Kamp, U.: Expanded and recently increased glacier surging in the Karakoram, Arct. Antarct. Alp. Res., 43, 503-516, 2011.

Cuffey, K. M. and Paterson, W.S.B.: The physics of glaciers, Elsevier, Oxford, 2010.

de Lange, R., Luckman, A., and Murray, T.: Improvement of satellite radar feature tracking for ice velocity derivation by spatial frequency filtering, IEEE T. Geosci. Remote, 45, 2309-2318, 2007.

Diolaiuti, G., Pecci, M., and Smiraglia, C.: Liligo Glacier, Karakoram, Pakistan: a reconstruction of the recent history of a surgetype glacier, Ann. Glaciol., 36, 168-172, 2003.

Fowler, H. J. and Archer, D. R.: Conflicting signals of climatic change in the Upper Indus Basin, J. Climate, 19, 4276-4293, 2006.

Frey, H. and Paul, F.: On the suitability of the SRTM DEM and ASTER GDEM for the compilation of topographic parameters in glacier inventories, Int. J. Appl. Earth Obs., 18, 480-490, 2012.

Frey, H., Paul, F., and Strozzi, T.: Compilation of a glacier inventory for the western Himalayas from satellite data: methods, challenges, and results, Remote Sens. Environ., 124, 832-843, 2012.

Gardelle, J., Berthier, E., and Arnaud, Y.: Slight mass gain of Karakoram glaciers in the early twenty-first century, Nat. Geosci., 5, 322-325, 2012.

Gardelle, J., Berthier, E., Arnaud, Y., and Kääb, A.: Region-wide glacier mass balances over the Pamir-Karakoram-Himalaya during 1999-2011, The Cryosphere, 7, 1263-1286, doi:10.5194/tc7-1263-2013, 2013.

Gardner, A. S., Moholdt, G., Cogley, J. G., Wouters, B., Arendt, A. A., Wahr, J., Berthier, E., Hock, R., Pfeffer, W. T., and Kaser, G.: A reconciled estimate of glacier contributions to sea level rise: 2003 to 2009, Science, 340, 852-856, 2013.

Harrison, W. and Post, A.: How much do we really know about glacier surging?, Ann. Glaciol., 36, 1-6, 2003.

Hewitt, K.: Glacier surges in the Karakoram Himalaya (central Asia), Can. J. Earth Sci., 6, 1009-1018, 1969.

Hewitt, K.: Natural dams and outburst floods of the Karakoram Himalaya, IAHS, 138, 259-269, 1982.

Hewitt, K.: Recent Glacier Surges in the Karakoram Himalaya, South Central Asia, http://www.agu.org/eos_elec/97016e.html (last access: 2 September 2013), EOS, American Geophysical Union, 1998.

Hewitt, K.: The Karakoram Anomaly? Glacier Expansion and the 'Elevation Effect,' Karakoram Himalaya, Mt. Res. Dev., 25, 332$340,2005$.
Hewitt, K.: Tributary glacier surges: an exceptional concentration at Panmah Glacier, Karakoram Himalaya, J. Glaciol., 53, 181-188, 2007.

Hewitt, K.: Glaciers of the Karakoram Himalaya. Glacial Environments, Processes, Hazards and Resources, Springer, Dordrecht, 2014.

Immerzeel, W. W., van Beek, L. P. H., and Bierkens, M. F. P.: Climate change will affect the Asian water towers, Science, 328, 1382-1385, 2010.

Immerzeel, W. W., Pellicciotti, F., and Shrestha, A.: Glaciers as a Proxy to Quantify the Spatial Distribution of Precipitation in the Hunza Basin, Mt. Res. Dev., 32, 30-38, 2012.

Jiang, Z., Liu, S., Peters, J., Lin, J., Long, S., Han, Y., and Wang, X.: Analyzing Yengisogat Glacier surface velocities with ALOS PALSAR data feature tracking, Karakoram, China, Environ. Earth Sci., 67, 1033-1043, 2012.

Jóhannesson, T., Raymond, C., and Waddington, E. D.: Time-scale for adjustment of glaciers to changes in mass balance, J. Glaciol., 35, 355-369, 1989.

Kääb, A., Berthier, E., Nuth, C., Gardelle, J., and Arnaud, Y.: Contrasting patterns of early twenty-first-century glacier mass change in the Himalayas, Nature, 488, 495-498, doi:10.1038/nature11324, 2012.

Kaser, G., Groshauser, M., and Marzeion, B.: Contribution potential of glaciers to water availability in different climate regimes, $\mathrm{P}$. Natl. Acad. Sci. USA, 107, 20223-20227, 2010.

Kienholz, C., Rich, J. L., Arendt, A. A., and Hock, R.: A new method for deriving glacier centerlines applied to glaciers in Alaska and northwest Canada, The Cryosphere, 8, 503-519, doi:10.5194/tc-8-503-2014, 2014.

Kotlyakov, V. M., Osipova, G. B., and Tsvetkov, D. G.: Monitoring surging glaciers of the Pamirs, central Asia, from space, Ann. Glaciol., 48, 125-134, 2008.

Luckman, A., Murray, T., Jiskoot, H., Pritchard, H., and Strozzi, T.: ERS SAR feature-tracking measurement of outlet glacier velocities on a regional scale in East Greenland, Ann. Glaciol., 36, 129-134, 2003.

Luckman, A., Quincey, D., and Bevan, S.: The potential of satellite radar interferometry and feature tracking for monitoring flow rates of Himalayan glaciers, Remote Sens. Environ., 111, 172181, 2007.

Mason, K.: Expedition notes: tours of the Gilgit Agency, Himalayan Journal, 3, 110-115, 1931.

Mayer, C., Lambrecht, A., Belò, M., Smiraglia, C., and Diolaiuti, G.: Glaciological characteristics of the ablation zone of Baltoro glacier, Karakoram, Pakistan, Ann. Glaciol., 43, 123-131, 2006.

Mayer, C., Fowler, A., Lambrecht, A., and Scharrer, K.: A surge of North Gasherbrum Glacier, Karakoram, China, J. Glaciol., 57, 904-916, 2011.

Meier, M. F. and Post, A.: What are glacier surges?, Can. J. Earth Sci., 6, 807-817, doi:10.1139/e69-081, 1969.

Murray, T., Strozzi, T., Luckman, A., Jiskoot, H., and Christakos, P.: Is there a single surge mechanism? Contrasts in dynamics between glacier surges in Svalbard and other regions, J. Geophys. Res., 108, 2237, doi:10.1029/2002JB001906, 2003.

Paul, F., Barry, R. G., Cogley, J. G., Frey, H., Haeberli, W., Ohmura, A., Ommanney, C. S. L., Raup, B., Rivera, A., and Zemp, M.: Recommendations for the compilation of glacier inventory data from digital sources, Ann. Glaciol., 50, 119-126, 2010. 
Paul, F., Bolch, T., Kääb, A., Nagler, T., Nuth, C., Scharrer, K., Shepherd, A., Strozzi, T., Ticconi, F., Bhambri, R., Berthier, E., Bevan, S., Gourmelen, N., Heid, T., Jeong, S., Kunz, M., Lauknes, T., Luckman, A., Merryman, J., Moholdt, G., Muir, A., Neelmeijer, J., Rankl, M., VanLooy, J., and van Niel, T.: The Glaciers Climate Change Initiative: Methods for creating glacier area, elevation change and velocity products, Remote Sens. Environ., in press, doi:10.1016/j.rse.2013.07.043, 2013a.

Paul. F, Huggel, C., and Kääb, A.: Combining satellite multispectral image data and a digital elevation model for mapping debriscovered glaciers, Remote Sens. Environ., 89, 512-518, 2013b.

Quincey, D. J., Copland, L., Mayer, C., Bishop, M., Luckman, A., and Belò, M.: Ice velocity and climate variations for Baltoro Glacier, Pakistan, J. Glaciol., 55, 1061-1071, 2009a.

Quincey, D. J., Luckman, A., and Benn, D.: Quantification of Everest region glacier velocities between 1992 and 2002, using satellite radar interferometry and feature tracking, J. Glaciol., 55, 596-606, 2009b.

Quincey, D. J., Braun, M., Glasser, N. F., Bishop, M. P., Hewitt, K., and Luckman, A.: Karakoram glacier surge dynamics, Geophys. Res. Lett., 38, L18504, doi:10.1029/2011GL049004, 2011.

Qureshi, A. S.: Water Management in the Indus Basin in Pakistan: Challenges and Opportunities, Mt. Res. Dev., 31, 252-260, doi:10.1659/MRD-JOURNAL-D-11-00019.1, 2011.

Racoviteanu, A. E., Paul, F., Raup, B., Khalsa, S. J. S., and Armstrong, R.: Challenges and recommendations in mapping of glacier parameters from space: results of the 2008 Global Land Ice Measurements from Space (GLIMS) workshop, Boulder, Colorado, USA, Ann. Glaciol., 50, 53-69, 2010.

Sarikaya, M. A., Bishop, M. P., Shroder, J. F., and Olsenholler, J. A.: Space-based observations of Eastern Hindu Kush glaciers between 1976 and 2007, Afghanistan and Pakistan, Remote Sensing Letters, 3, 77-84, 2012.

Sarikaya, M. A., Bishop, M. P., Shroder, J. F., and Ali, G.: Remotesensing assessment of glacier fluctuations in the Hindu Raj, Pakistan, Int. J. Remote Sens., 34, 3968-3985, 2013.

Scherler, D. and Strecker, M. R.: Large surface velocity fluctuations of Biafo Glacier, central Karakoram, at high spatial and temporal resolution from optical satellite images, J. Glaciol., 58, 569-580, 2012.
Scherler, D., Bookhagen, B., and Strecker, M.: Spatially variable response of Himalayan glaciers to climate change affected by debris cover, Nat. Geosci., 4, 156-159, 2011.

Shekhar, M. S., Chand, H., Kumar, S., Srinivasan, K., and Ganju, A.: Climate-change studies in the western Himalaya, Ann. Glaciol., 51, 105-112, 2010.

Strozzi, T., Luckman, A., Murray, T., Wegmüller, U., and Werner, C.: Glacier motion estimation using SAR offset-tracking procedures, IEEE T. Geosci. Remote, 40, 2384-2391, 2002.

UNDP - Bureau for Crisis Prevention and Recovery: Glacial lake outburst floods, www.managingclimaterisk.org/index.php? menu_id=2\&pagetype_menu=2\&content_id=MEN-2, last access: 10 December 2013.

Weiers, S.: Zur Klimatologie des NW-Karakorum und angrenzender Gebiete. Statistische Analysen unter Einbeziehung von Wettersatellitenbildern und eines Geographischen Informationssystems (GIS), Ph.D. thesis, University of Bonn, Germany, 1993.

Werner, C., Wegmüller, U., Strozzi, T., and Wiesmann, A.: Precision estimation of local offsets between pairs of SAR SLCs and detected SAR images, Proceedings of IGARSS '05, 4803-4805, 2005.

Wilcoxon, F.: Individual comparisons by ranking methods, Biometrics Bull., 1, 80-83, 1945.

Williams, R. J. and Ferrigno, J.: Glaciers of Asia: U.S. Geological Survey Professional Paper 1386-F, United States Government Printing Office, Washington, 2010.

Winiger, M., Gumpert, M., and Yamout, H.: KarakorumHindukush-western Himalaya: assessing high-altitude water resources, Hydrol. Process., 19, 2329-2338, 2005.

Yao, T., Thompson, L., Yang, W., Yu, W., Gao, Y., Guo, X., Yang, X., Duan, K., Zhao, H., Xu, B., Pu, J., Lu, A., Xiang, Y., Kattel, D. B., and Joswiak, D.: Different glacier status with atmospheric circulations in Tibetan Plateau and surroundings, Nature Climate Change, 2, 663-667, doi:10.1038/nclimate1580, 2012. 